\title{
Normalization of Sexuality in Gender Procedures: An Analysis of Language and Gender
}

Morteza Farhadytooli (Corresponding author)

The Department of Gender Studies, University of Cyprus, Nicosia, Cyprus

Email: farhadytooli.morteza@ucy.ac.cy

Received: 04/11/2021

Accepted: 09/02/2022

Published: 01/03/2022

Volume: 3 Issue: 2

How to cite this paper: Farhadytooli, M. (2022). Normalization of Sexuality in Gender Procedures by Analysing Theoretical Frameworks of Language and Gender. Journal of Critical Studies in Language and Literature, 3(2), 20-25

DOI: https://doi.org/10.46809/jcsll.v3i2.137

This work is licensed under the Creative Commons Attribution International License (CC BY 4.0). http://creativecommons.org/licenses/by/4.0/

\section{(c) (i)}

\section{Abstract}

Normalization of sexuality in gender procedures, especially the focus on theoretical frameworks of language and gender, is the main concern in this study. This study argues that gender is understood as a social phenomenon and sex as a social material and the main concentration in the research is the investigation into the use of specific frameworks to confirm the idea that there are explicit systems among normalization the sex and gender procedures for either male or female that are affected by the language and gender theories. Indeed, sexual differences are legitimized by the nature of the two-sex system and according to this system normal gender is the social sex of women and men. This is derived from the biological sex. The result of this paper can partly contribute to the language and gender usage areas as well as other academic fields such as sociolinguistics and gender studies.

Keywords: Normalization, Sexuality, Gender Procedure, Gender, Language

\section{Introduction}

This study analyzes the role of language and gender frameworks on the normalization of the sexes in gender procedures. It seems that normalization can be described as a transformation of gender procedures and sexual desires in societies. This study starts by the question of how gender and sex through the living body are understood as a material of language and discourse? And, how does this material of discourse normalize sexual desires? This concept that the category of gender is understood as a discourse phenomenon has arisen within the flexible gender procedures and represents the basis for the symbolic system of sexuality. One should always remember that every person should be either female or male, which has to be recognizable when dealing with sexual desires. In this case, the living body throughout the sexual desire must be physically recognized and justified, but here the question is raised, is it always understood or is it simply become justified? Who is going to legitimate sexuality or sexual desire and who is going to understand sexuality as a normal or abnormal phenomenon? It seems that there are a lot of presuppositions that deal with individual bodies to orient them in specific sexual ways and normalize them through those orientations. One of the most important and significant essentials of sexual procedures and their assumption is a linguistic discourse. On the one hand, theories including language and gender or sexuality unreflectively adopt the everyday assumptions of the society around it remains attached to the power and domination relationships of the society. And on the other hand, the majority of theories cover the gender and sexualities established based on heterosexuality. Therefore, differences between the two sexes (male and female) are always constructed in everyday life as inequality and as concrete oppression. Furthermore, one should not forget that we cannot afford to assume the existence of two and only two sexes, because it is not an extra social, natural and unchangeable fact. Indeed, the Intellectual and feeling of people ultimately also 
serves to control and understand the bodies and sexual desires. By and large, in the following, we will first shed light on the concept of gender procedures and sexual desires. By establishing a literature review and using target keywords such as; gender, sex, sexuality, desire, language and gender frameworks, sexual normalization, etc., we will evaluate and analyze the different studies and papers which are related to the aim. Then, equally relevant to this issue we will analyze the role of language and gender perspectives for the normalization of sexuality in gender procedures. In fact, language carry and represent the various collections of life such as; history, culture, tradition, stereotype and so on. Therefore, the role of language in representing gender identity requires the individuals' knowledge and perception on the one hand and theoretical and logical thinking of language and gender on the other. In addition, the language and gender frameworks that are studied by researchers have not gone beyond the gender identity knowledge and have made significant differences in understanding the identities and procedures of the gender. Therefore, we should consider the frameworks of language and gender with a development viewpoint and identify them from a knowledge-based perspective that pays attention to all aspects of individuals' life in related disciplines that normalized gender and sexuality. The purpose of this research is to explore the theoretical frameworks of language and gender and represent the role of these frameworks on the normalization of the sexes in gender procedures.

\section{Literature Review}

One of the most striking features of the gender is different categories of gender perspective which are included, biological gender or sex (based on the anatomy), grammatical gender (based on language and linguistics), and social gender (based on functions, characteristics, and social roles). Indeed, gender represents the identity of an individual, and the use of gender can be considered as an act of identity. Foucault (1978) mentioned that the idea of sexuality as identity, and of homosexuals and heterosexuals as "types", emerged in the West in the 19th century. He claimed that the description and regulation of sexual conduct and gender identities were no more about religion or morals but about science. Equally relevant to this issue, language and gender science and linguistics displayed the different theories about language and gender. Historical frameworks to analyze the interface and dialectics of gender and language are represented in four basic frameworks. Although there are some other theories such as comprehensive or structural, etc. it seems that these theories are under the shelter of four major perspectives that are going to be examined in this paper.

Lakoff (1975) and Jespersen (1922) uttered the "deficit theory" which enclosed the men's and women's styles of speech and they got to this idea that men's speech is considered the norm and women's not. Based on this idea the lexical and phonological differences are observed and it represents that language change can be based on social and gendered roles and it suggested that gender roles influence language. Mikić (2020) in his study analyses the different models that were made to create the patterns and styles of the language used by men and women in Western countries. He claimed that the major concept in research "was the women's language, regarded as inferior and subject to pejorative connotations" (p. 239). He also represented that language and gender models are fundamental for the research about gender and language but "they are largely no longer considered current due to the many shortcomings of their theory and weak empirical support" (ibid).

Dale Spender (1980) supported the "dominance theory" and she claimed that the using language in the world is biased against women, indeed the second theory is about power, not gender. In other words, she believed that any difference in the ways men and women speak are mostly the results of their "subordinate position" in society relative to men, "not the results of their gender". Therefore, any difference "relates to power difference" and reflects differences in gender roles. Cameron (2005) by studying the language, gender, and sexuality as current issues and new directions represent that in the past years "the concept of binary difference has been superseded by one that is concerned with the diversity of gendered and sexual identities and practices" (p. 482). She also discussed the "postmodern turn" which is a theoretical foundation for the shift in approaches. Nevertheless, she claimed, understanding the gender in this world by considering the unjust and oppressive effects, "requires us to pay close attention to the similarities and differences... crucially including what may be very marked differences in how much power, control, or choice they have" (P. 499). It is clear that language is more than just an implement for communication, Jaber (2022) in his study represented, on the one hand, language "carry the histories, cultures, traditions, and experiences of people who speak it" and on the other hand, it "represents collections of shared cultural values and customs that uniquely identify speakers in a social setting and, as a result, make it for them to be recognized hence giving them a sense of belonging" (p. 81). But it seems that by carrying the historical and cultural values language is always gendered. For example, Elaziz Mahmoud (2021) by analyzing the gendered portrayal of characters in Disney princesses' movies said that the language of three princesses from three films produced in three different periods of time represent the changes in the discourse and language of the princesses, indeed, "[F]features that have been perceived as feminine disappeared gradually, and the verbal utterances of the three protagonists may have become more forceful" (p. 21)

Another framework that is supported by Deborah Tannen (1994) characterized the differences between men and women but the "difference theory" considers being different but being equal as well. For instance, men rapport a competitive style, and women want a cooperative style. Therefore, both groups develop different social strategies to get what they want, "directness vs. indirectness". Foster (1999) in her study focused on the feminist and misunderstanding the difference theory. She said the gender theory and sexual differences "rely on different conceptualizations of fundamental concepts in feminist theory, including notions of gender, sexuality, and symbolic" (p. 431). She comes to the conclusion that "gender theory allows feminist scholars to ask a wider range of empirical questions that are more readily of use for political action than does a sexual difference paradigm" (ibid). Garcia (2022), in her study, focused on "The Language of Entrepreneurship: An Exploratory 
Gender-Coding Study" and examined the role of language in endorsing this issue. The results of her study suggested that "gender is not the delineating factor in masculine and feminine approaches to entrepreneurship; instead a strong distinction exists between entrepreneurs, who have a more masculine viewpoint, and non-entrepreneurs, who have a balanced viewpoint" (p. 357).

And finally, the "post-modern theory" (Hall \& Bucholtz 1995 and Deborah Cameron 1998) came with a new idea that is "all a question of style". For example, when speaking or writing a text, multiple factors are at play, we choose which socially is the most appropriate style or gendered constructed style at the time of communication. Indeed, we can then do gender. In the post-modern perspective, the meaning of masculinity and feminity and in general the meaning of identity is addressed by rethinking gender and identity. To illustrate this point Phillips (2009) indicated postmodernism analyze and rethink the sex or gender identity, in other words, "postmodern positions exploring sex as a biological given, the emerging critiques of differentiating sex and gender, and poststructural psychoanalytic positions on simultaneous production of individual subjectivity (sense of self), identity, and society (p. 403). Tuo and Liu (2022) in their study examined the "Gender performativity in Doris Lessing's the Clieft" and they presented the different gender norms and discursive practices and performativity of gender in this novel. Moreover, the result of their study showed "the gender identity is not fixed but unstable, which breaks the thinking mode of dualism" (p. 9). This idea of gender identity manifests the performativity theory of gender which is introduced by Judith Butler. According to Rak (2022) performativity in Butler's view explains how gender identity constructs subjects and then is connected to ideas about sex assignment, bodies and sexuality.

\section{Findings and Results}

According to Oxford English Dictionary, sexuality is "the quality of being sexual or having sex... capability of sexual feelings... the fact of being heterosexual, homosexual, bisexual; sexual orientation". It is undeniable that the idea of sexuality is linked to a person's identity which is defined with different words and ideas throughout human history. We did not have fixed and permanent sexuality to define and express our identity, rather we have gained and lost diverse sexualities and identities in history. Our sexual desire always changes by the social phenomena and we orient ourselves in a way those phenomena pleased. According to Foucault (1978) in The History of Sexuality, for a long time, a certain kind of sexuality derived in the societies, "[S]sexual practices had little need of secrecy; words were said without undue reticence, and things were done without too much concealment" (p. 3). But at the Victorian bourgeoisie period, the usage of sexuality changed and it moved into the home just for "production" and "reproduction". Foucault's study of the history of sexuality represents the following:

Nothing that was not ordered in terms of generation or transfigured by it could expect sanction or protection. Nor

did it merit a hearing. It would be driven out, denied, and reduced to silence. Not only did it not exist, it had no right

to exist and would be made to disappear upon its least manifestation whether in acts or in words. (ibid, p. 4)

It is very clear from these observations that a certain kind of sexuality is always driving in history and always works based on heterosexual desires. Those descriptions and regulations of sexual conduct were governed by morals and religion and other sexual institutions and also their orientations are repressed in a specific way in a specific period of time. Meanwhile, we should also consider that "the idea of sexuality as an identity and homosexuals and heterosexuals as a type, emerged in the West in the 19th century" (ibid, p. 68).

Another important aspect of the research problem is gender procedure, and it would be unfair not to mention the concept of gender procedures. Biological and social gender as well as the social systems are viewed as a heterosexual construction. It means that gender categories and orientations form based on the symbolic system of two types of sexes which are included, male and female. The system of two-sex and naturality is understood as products of social practices that are first reproduced again and repeated again through discourse and non-discourse of linguistic power. By non-discourse practices, we mean, the everyday performance of individuals as men or women, as doing gender, as bodily experiences which identities and classifies people as a male or female which Tyrell (1986) called it as a "Bisexual identification service... gender-specific socialization practices and the gender-specific division of labor" (p. 452). On the contrary, the term discourse practices refer to the particular procedure which is culturally produced images, norms, and concept of identity and socially understood via language practices. The difference between discourse and non-discourse practices could be complicated. According to Burmann (1988), discourse and non-discourse practices are interrelated: "discourse practices serve to orient individuals in everyday practice and nondiscourse practice in the sense of effects, force discourse practices" (p. 77). For example, the fact that most people believe that they have an unchangeable, unambiguous, and naturally given gender will lead to them orienting themselves towards the gender-specific identity concepts that are propagated as normal by human knowledge. At the same time, for example, transsexuals or intersex people will suffer from denormalization fears. Therefore, if an individual understands the system of sexuality and the gender categories as a phenomenon that has been or will be produced through language and discourses within the gender procedures, then gender and sexuality is no more natural, unchangeable, and nonetheless as existing "socially cultural materiality" (Maihofer, 1995, p. 84).

To illustrate the above point, one needs to refer to the gender and language frameworks that work to construct the individual's identities and make them be normal and understandable. The question is not simply whether such works participate in recognizable and normalizable identities of individuals as if that would suffice to guarantee their protected status. Meanwhile, the features of gender procedures, particularly gender and sexuality are part of a social system that is tied into 
language. For instance; making a decision or accessing high places are mostly in the domination of masculinity because men's style of speech is always considered "powerful and natural", while women's style is always understood as "powerless and nurture" (Cameron, 2005, p.14). The deficit theory of language and gender declares that "stronger expletives are reserved for men, and the weaker ones for women" (Lakoff, 1975, p. 245). Although, this represents the clear differences between men and women, but it displays the dominion of masculinity over femininity as well. It is very clear from these observations, what we see in the world around us "depends in a large part on the principles we have encoded in our language" (Spender, 1980, p. 95). These encoding rules are in a favour of masculinity to dominate other gender and it is "men who have made the world which women must inhabit" (ibid, p. 93). Because language is not neutral. It is not merely a "vehicle which carries ideas. It is itself a shaper of ideas, it is the program for mental activity" (ibid, p. 94).

Therefore, it seems that it is about power not gender, a power which is carried by men throughout the society, "those who have the power to make the symbols and their meanings are in a privileged and highly advantageous position" (Spender, 1980, p. 97). From this observation, it can be seen that those who have the power are in a position to influence reality, and because it has been "males who have named the world" (ibid, p. 99), therefore, they have the power to dominate over genders. In spite of the deficit and dominance theory, difference theory also represents the subordination of femininity and the domination of masculinity as well. Although there are differences between the linguistic forms or styles of men and women, like "competitive and cooperative style", but both by different styles and "different social strategies learn to get what they want" (Tannen, 1994, p. 274). Nevertheless, as long as women generally bear the power of language and easily accept its principles, the man is the stronger and their style of language more individually natural and as the same way the language will remain more sexist and, accurately, "sexist values influence the meanings of terms that already exist in a language" (Ehrlich \& King, 1992, p. 166). Therefore, sexism in how we speak has many aspects, and "women are frequently the victims of male oppression in discourse" (McConnell-Ginet, 1989, p. 198). These arguments illustrate that language is male and women or queers' style of speech always remains in a subordinate position. Subsequently, the words which are referred to the women or queers like; "cunt or fag" would always put an individual in a lower place. For example; individuals use words which is related to women or queers to address others to empower their dominance. In this case, when a person says; "don't be fag, you can study anytime" or "come on, you big homo, you can have one beer" (Armstrong, 1997, p. 330), it is not just a word to humiliate others, rather it carries an action which is manifested the lower place of homos as well. By calling "fag" or "homo", a subject being a sexual subject, "a subject who did not pre-exist the call, but became and constructed as a subject by call" (Kulick, 2003, p. 290). Thus, it seems that presenting non-sexist terms and phrases into a language will not necessarily lead to non-sexist usage. The way we speak and perform represents our gender identity. Therefore, when we say something, we initiate and perform an action and form the subjects who are available and visible to us. For example; the utterance; "It's a girl" delivered by a doctor to a mother who has just given birth are not merely a descriptive phrase, "the utterance performs an act, the act of naming initiates the process by which a certain girling is compelled” (Butler, 1993, p. 232). We can also go further and take Althusser's (1970) idea about "calling and naming" and making a subject by "interpolating" an individual and also clarify it by Butler's perspective, how after calling and naming an individual, he/she starts to perform a specific identity and understand himself/herself as a specific subject. In the famous scene of interpellation that Althusser provides, the policeman hails or calls the pedestrian with a phrase "hey you there" and the one who recognizes himself/ herself and also itself and turns around to answer the call "does not, strictly speaking, preexist the call” (Butler, 1997, p. 25). Butler thinks that Althusser's scene is wonderful, but what could it mean? She says, "[T]the passerby turns precisely to acquire a certain identity, one purchased, as it were, with the price of guilt. The act of recognition becomes an act of constitution: the address animates the subject into existence" (ibid, p. 25).

In order to determine the concept of gender procedures, we do first consider the historical perspective of gender. Therefore, at first, the focus of my study is on the normalization of the differences and historical transformation which lies in societies. By making a critical view on the history of sexuality we can find out the close connection between power and gender throughout history. Male and female desire gradually develop based on the diversity of the body and how this division into two could be understood as given biologically. Foucault assumes that the division of the original multiplicity of bodies into two and the constitution of some as subjects take place within the framework of instances of normalization. These bodies, which are essentially based on one or more norms, normalize people through the creation of new knowledge. It turns people into women and men. Foucault (2007) calls this new type of power, "bio-power". He says, by this I mean a number of phenomena that seems to me to be quite significant, "namely, the set of mechanisms through which the basic biological features of the human species become the object of a political strategy, of a general strategy of power" which process reflect "how, starting from the eighteenth century modern societies took on board the fundamental biological fact that human beings are a species" (Foucault, 2007, p. 16). Therefore, for Foucault, bio-power was not something that happened to society, but rather something that was produced or invented by society itself, something which controls the living bodies and govern them by moral and religion and other sexual institutions which are repressed in the specific orientations and frameworks. Indeed, sexuality functions became a material between the individual's body and the bio-power and through which the individuals are disciplined and individualized, became normalized. The framework of gender categories and orientations is formed based on the symbolic system of two types of sexes which is included, male and female. The system of two-sex and naturality is understood as products of social practices that are first reproduced through language and language's power.

It is clear that gender and language are deeply contacted and influenced each other, but it is not simply because of the natural differences between men and women. The way people use the language can be related to the social system where they belong, their habitual activities, their identities as particular acts and performances, and their status related to others. All of 
these elements are potentially affected by gender and language perspectives. Language and gender theories bring out a lot of binary perspectives that women and men develop different patterns, they tend to focus on different functions, they use different styles to represent their sexual orientations and a lot of ideas which is easily focused on the domination and transformation powers between male and female. Therefore, it seems that language and gender theories cause dominion in societies and lead us to understand the male and female belonging in different worlds, "men are from Mars, women are from Venus" (Gray, 1992). And particularly, it is represented the power of masculinity which is illustrated that language is male and women or queers always remain in a subordinate position. Subsequently, the usage of language which is refer to the women or queers would always put an individual in a lower place. Consequently, it causes that male's style of language and particularly its gender and sexuality as a natural and normal and female and queers as a hysteric and researchable.

In order to understand the usage of language, we need to understand the performance of language in a different number of ways. For example, the usage of language which performs as an act is developed by J. L Austin (1962) "How to do Things by Words" and he united it into speech act theory which is later used by Butler to explain the politics of performativity and gender acts. According to Butler, gender is always a doing and performativity can be understood as the way in which we do or perform an act to show our identity. In Butler's sense, gender or sexuality is a self-producing activity that is not free to choose, rather occurs within the social and discursive regulation framework. Therefore, Butler's view of the notion of performativity manifests several implications of language acts. It illustrates the way of understanding the subject's identity and how a subject interpellated into being by using language, naming, or calling. Thus, the arguments of language and gender frameworks are not how do men and women talk differently. It seems that men and women have already constituted their own identities by using pre-exist language principles to manifest the specific categories of gender and sexuality, or "by recalling Austin once again, how to do gender with words" (Pennycook, 2009, P.13).

\section{Conclusion}

To sum up, the most satisfactory conclusion that we can come to is human knowledge and history established gender procedures. Indeed, gender is understood as a social phenomenon and sex as a social material and normalized the individual's sexuality based on this knowledge. Hence, humans as a male and female individuals must be socialized and identified to became understandable. In this case, the style of a man is considered as nature and woman as nurture. This form of socialization led the living body to motherhood and tied with subordination and at the same time made the other powerful and dominant. Moreover, sexual differences are legitimized by the nature of the two-sex system. According to this system normal gender is the social sex of women and men which is derived from the biological sex. Although with regard to the language usage and gender styles, women and men and their binary sexual desire are now normalized, but it seems that language and gender theories led to just normalizing the binary sexuality as normal and understandable and others abnormal and queer. Nevertheless, the concept of sexual desire and sexuality still is a fundamental issue when an individual finds itself related to the identity. The way one performs opens up a variety of identities and sexual categories, and those identities, are easily formed in the linguistic performance. This perspective of language and gender relationship also helps us to see and understand, how an individual find itself and its identity as a specific subject when they are called in Althusserian interpellation.

\section{References}

Althusser, L. (1970). Ideology and Ideological State. Published by Verso.

Armstrong, J. (1997). Homophobic slang as a coercive discourse among college students. Queerly Phrased: Language, Gender, and Sexuality, New York: Oxford University Press, 325-334.

Austin, J. L. (1962). How to do Things by Words. Oxford University Press.

Buhrmann, A. D. (1998). The normalization of the sexes in gender dispositifs. The sex of modernity: Genealogy and archeology of the gender difference, pp. 71-94.

Butler, J. (1993). Bodies that Matter: On the Discursive Limits of 'Sex'. New York: Routledge.

Butler, J. (1997). Excitable Speech. New York: Routledge.

Cameron, D. (1998). Performing Gender Identity: Young Men's Talk and the Construction of Heterosexual Masculinity. In J. Coates (ed.) Language and Gender: A Reader. Oxford: Blackwell, pp. 270-84.

Cameron, D. (2005). The Feminist Critique of Language: A Reader. New York: Routledge.

Cameron, D. (2005). Language, Gender, and Sexuality: Current Issues and New Directions. Applied Linguistics, Volume 26, Issue 4, Pages 482-502, https://doi.org/10.1093/applin/ami027

Ehrlich, S \& King, R. (1992). Gender Based Language Reform and the Social Construction of Meaning. In D. Cameron (Ed.), The Feminist Critique of Language: A Reader (pp. 164-182). New York: Routledge.

Elaziz Mahmoud, N. K. (2021). Language and Gender Analysis of Three Walt Disney Movies: A Study of Female Language Features of Three Princesses. Egyptian Journals Aladab. 52 (1), 1-23.

Foucault, M. (2007). Security, Territory, Population: Lectures at the Collège de France 1977-78. Trans. G. Bucknell. London: Palgrave Macmillan.

Foucault, M. (1978). The History of Sexuality Volume I. New York: Pantheon Book. 
Foster, J. (1999). An Invitation to Dialogue: Clarifying the Position of Feminist Gender Theory in Relation to Sexual Difference Theory. Gender \& Society.13(4):431-456. https://doi.org/10.1177/089124399013004002

Garcia, R. (2022). The Language of Entrepreneurship: An Exploratory Gender Coding Study. World Scientific Encyclopedia of Business Sustainability, Ethics and Entrepreneurship, pp. 357-389. https://doi.org/10.1142/9789811248863_0013

Gray, J. (1992). Men are from Mars, Women are from Venus. New York: Harper Collins.

Hall, K \& Bucholtz, M. (1995). Gender Articulated: Language and the Socially Constructed Self. New York: Routledge.

Jaber , R. S. (2022). Language and Identity in Iraqi Arabic: A Gender-Based Study. International Journal of Linguistics, Literature and Translation, 5(2), 81-92. https://doi.org/10.32996/ijllt.2022.5.2.11

Jespersen, O. (1922). Language, its nature, development, and origin. New York, Henry Holt and Co.

Kulick, D. (2003). No. In D. Cameron \& D Kulick (Eds.), The Language and Sexuality Reader (pp. 285-293). New York: Routledge.

Lakoff, R. (1975). Extract from Language and Woman's Place. In D. Cameron (Ed.), The Feminist Critique of Language: A Reader (pp. 242-252). New York: Routledge

Maihofer, A. (1995). Gender as a Way of Existence. Power, morality, law and gender difference Journal. Frankfurt

McConnell-Ginet, S. (1989). The Sexual (Re)Production of Meaning: A Discourse Based Approach. In D. Cameron (Ed.), The Feminist Critique of Language: A Reader (pp. 155-163). New York: Routledge.

Mikić, J. (2020). A Historical Overview of Research into Gender and Language: From the Deficit Model to the Social Constructivist Model. Slovensko sociološko društvo (in FDV). Issue 36 (94-95), Page Range: 239-260

Oxford English Dictionary.

Pennycook, A. (2209). Performativity and Language Studies. Critical Inquiry In Language Studies: An International Journal, 1:1, 1-19, https://doi.org/10.1207/s15427595cils0101_1

Phillips, D. A. (2006). Masculinity, Male Development, Gender, and Identity: Modern and Postmodern Meanings. Mental Health Nursing. 27:4, 403-423. https://doi.org/10.1080/01612840600569666

Rak, J. (2022). Performativity. Oxford Research Encyclopedia of Literature. Retrieved. https://oxfordre.com/literature/view/10.1093/acrefore/9780190201098.001.0001/acrefore-9780190201098-e-1079.

Spender, D. (1980). Extracts from Man Made Language. In D. Cameron (Ed.), The Feminist Critique of Language: A Reader (pp. 93-99). New York: Routledge.

Tannen, D. (1994). The Relativity of Linguistic Strategies; Rethinking Power and Solidarity in Gender and Dominance. In D. Cameron (Ed.), The Feminist Critique of Language: A Reader (pp. 261-279). New York: Routledge.

Tuo, Gh \& Liu, H. (2022). Gender Performativity in Doris Lessing's the Cleft. Research Journal of English Language and Literature. 10 (1), 9- 14.

Tyrell, H. (1986). Gender differentiation and gender classification. Cologne Journal for Sociology and Social Psychology, Issue 38, pp. 450-489. 